\title{
Hemşirelerde Algılanan Stres ve Stres Semptomlarının İşten Ayrılma Eğilimi Üzerindeki Etkisi
}

\author{
Dr. Öğr. Üyesi Gülşen Çetin Aydın ${ }^{1 *}$ \\ Prof. Dr. Serpil Aytaç ${ }^{2}$ \\ Dr. Öğr. Üyesi Yasemin Şanlı ${ }^{3}$
}

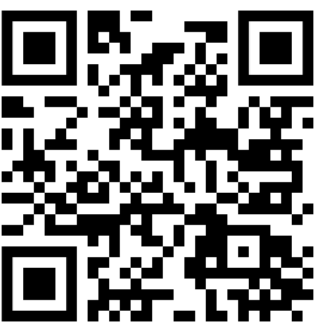

Geliş tarihi: 02.09.2020

Kabul tarihi: 28.11 .2020

\section{Atıf bilgisi:}

IBAD Sosyal Bilimler Dergisi

Sayı: Özel Sayı Sayfa: 526-538

Yıl: 2020

This article was checked by iThenticate. Similarity Index 19\%

Bu makalede araştırma ve yayın etiğine uyulmuştur.

\footnotetext{
${ }^{1}$ Karamanoğlu Mehmetbey Üniversitesi, Türkiye,gulsenaydin@kmu.edu.tr, ORCID ID 0000-0002-8371-2251

2 Bursa Uludağ Üniversitesi, Türkiye, saytac@uludag.edu.tr. ORCID ID 0000-0001-6659-4639

${ }^{3}$ Karamanoğlu Mehmetbey Üniversitesi, Türkiye, yaseminsanli@kmu.edu.tr, ORCID ID 0000-0001-9169-0577
}

* Sorumlu yazar
ÖZ

Sağlık hizmetlerinin kalitesi kullanılan ekipman ve teçhizatın yanı sıra mutlu sağlık çalışanları ile ilişkilendirilmektedir. Ancak stres, çalışma yaşamında personelin verimliliğini, mutluluğunu, iş tatminini ve buna bağlı olarak da özel yaşamını olumsuz etkileyen ve işten ayrılma eğilimini arttıran önemli bir faktördür. Sağlık sektöründe hizmet veren meslek gruplarından en yoğun çalıșma temposuna sahip olan hemşirelik, stresten en çok etkilenen meslektir. Bunun temel sebebi olarak uzun ve yorucu çalıșma saatlerini, zamana karșı yarıș halinde olmalarını, fiziksel çalışma koşullarını, nöbet sistemiyle çalışmalarını, iş yükü vb. olduğunu söylemek mümkündür. Bu sebeplerden kaynaklı olarak yaşadıkları uykusuzluk, yetersiz ve kötü beslenme, çalışma arkadaşları arasındaki çatışma, rol belirsizliği gibi baskı ve zorlama yaratan durumlar, stres düzeylerinin artmasına sebep olmaktadır. Kalpdamar sistemi hastalıkları, dolaşım sistemi bozuklukları, üreme sistemi hastalıkları, deri hastalıkları, baş ağrısı ve migren vb. rahatsızlıklar, yaşanan stresin fizyolojik etkilerini ortaya koymaktadır. Diğer taraftan depresyon, kaygı vb. psikolojik olarak da sorunlara yol açmaktadır. Bu bağlamda bu çalışma, bir devlet hastanesinde görev yapan hemşirelerin çalışma yaşamında algıladıkları stres ve ortaya çıkan stres semptomlarının işten ayrılma eğilimi üzerindeki etkisini ölçmeyi amaçlamaktadır. İșten ayrılma eğiliminin stres semptomlarıyla tutarlı korelasyonlar sergileyeceği ve bu semptomların işten ayrılma eğilimini etkileyeceği beklentisi, araştırmanın temel hedefini oluşturmuştur. 263 kişilik bir hemşire örnekleminden elde edilen bulgulara göre, iş stresindeki artışın, işten ayrılma eğilimini arttırdığı $(r=0,34, p>0,001)$, anksiyete, depresyon, olumsuz benlik, somatizasyon ve hostilite adını taşıyan beş ana stres semptom grubuna ilişkin verilerin işten ayrılma eğilimiyle olan ilişkide korelasyonlar olumsuz benlik alt semptomu hariç diğerleriyle pozitif yönde ve istatistiksel açıdan anlamlı olmakla birlikte, en yüksek korelasyonun hostilite semptom grubuyla elde edildiği $(r=0.21, p>0.001)$; bireylerin hostilite düzeyleri arttıkça, işten ayrılma eğilimlerinin arttığı anlaşılmıştır.

Anahtar Kelimeler: Stres, hemşire, işten ayrılma eğilimi, stres düzeyi, semptom. 


\title{
The Effects of Perceived Stress and Stress Symptoms on Nurses' Tendency to Leave Work
}

\author{
Assist. Prof. Dr. Gülşen Çetin Aydın ${ }^{1 *}$ \\ Prof. Dr. Serpil Aytaç ${ }^{2}$ \\ Assist. Prof. Dr. Yasemin Şanlı ${ }^{3}$
}

First received: 02.09 .2020

Accepted: 28.11 .2020

\section{Citation:}

IBAD Journal of Social Sciences

Issue: Special Issue

Pages: 526-538

Year: 2020

This article was checked by iThenticate. Similarity Index 19\%

1 Karamanoglu Mehmetbey University, Turkey, gulsenaydin@kmu.edu.tr, ORCID ID 0000-0002-8371-2251

2 Bursa Uludag University, Turkey, saytac@uludag.edu.tr,

ORCID ID 0000-0001-6659-4639

3 Karamanoglu Mehmetbey University, Turkey, yaseminsanli@kmu.edu.tr, ORCID ID 0000-0001-9169-0577

* Corresponding Author

\begin{abstract}
The quality of healthcare services is correlated with happy healthcare professionals as well as the equipment used. However, stress is an important factor in working life, which negatively affects the productivity, happiness, job satisfaction, and consequently the private life of the staff and increases the tendency to leave. Nursing, which has the most intense working tempo of the occupational groups serving in the health sector, is the profession most affected by stress. It is possible to say that the main reasons of this are long and tiring working hours, being in a race against time, physical working conditions, working with the shift system, workload and so on. Due to these reasons, situations that create pressure and compulsion such as insomnia, poor diet, malnutrition, the conflict between colleagues, role ambiguity causes an increase in stress levels. Some disorders like cardiovascular system diseases, circulatory system disorders, reproductive system diseases, skin diseases, headache, and migraine reveal the physiological effects of the stress experienced. On the other hand, depression and anxiety like diseases also cause psychological problems. In this context, this study aims to measure the effect of perceived working life stress and stress symptoms of nurses working in a public hospital on the tendency to leave. The expectation that the tendency to leave the job will exhibit consistent correlations with the stress symptoms and that these symptoms will affect the tendency to leave the job constituted the main target of the study. According to the findings obtained from a sample of 263 nurses, it is understood that the increase in job stress increases the tendency to leave $(r=0,34$, $\mathrm{p}>0,001)$. The correlations of the data related to five main stress symptom groups named as anxiety, depression, negative self, somatization, and hostility in the relation with the tendency to leave are positive and statistically significant with the others except for negative ego sub-symptom. The highest correlation is obtained with the hostility symptom group $(r=0.21, p>0.001)$, and it is also understood that as the hostility level of individuals increases, the tendency to leave their jobs also increases.
\end{abstract}

Keywords: Stress, nurse, tendency to leave, stress level, symptom. 


\section{GİRIŞ}

İnsanı temel alan çalışmaların genelinde daha iyi bir yaşam düzeyine ulaşma amaçlanmaktadır. Bu sebeple gerek bireysel gerekse toplumsal konuların temelinde insan unsuru yer almaktadır. Özellikle son yıllarda çalışma yapısının değişmesiyle birlikte yaşam kalitesinin arttırılmasına oldukça önem verilmektedir. Önceleri bir meta aracı gibi görünen insan, artık kıymetli bir sermaye kaynağı olarak görülmektedir. $\mathrm{Bu}$ sebeple yapılan bilimsel çalışmaların temelinde insanlığa yönelik daha iyi bir yaşam sunma düşüncesi yer almaktadır. Ancak stres ve strese etki eden faktörler yaşam kalitesini büyük ölçüde etkilemektedir.

Stres olgusu gerek günlük yaşamda gerekse çalışma yaşamında sıklıkla gündeme gelmektedir. Özellikle çalışma yaşamında meydana gelen gelişmeler sonucu bireylerin, yeni çalışma biçimlerine uyum sağlamaları ve ortaya çıkan belirsizliklerle mücadele etmelerine gereksinim duyulmaktadır (Önder ve diğerleri, 2014, s. 22). Bu düşünceden hareketle stres ve etkilerinin en çok görüldüğü meslek grubu olan hemşirelerin maruz kaldıkları iş stresi ele alınmak istenilmiştir.

Literatürde çalışma koşulları kıyaslandığında hemşireliğin en stresli mesleklerden biri olduğunu ifade etmektedir. Özellikle hemşirelerin maruz kaldığı stresin işteki performanslarını doğrudan etkilediğini ve bu konuda hassas davranılması gerektiğini vurgulamaktadır. (Selye, 1976; Newlin, 1984; Boswell, 1992). Hemşirelik mesleği başlarda doktorların yardımcısı olarak görülse de ilerleyen yıllarda sağlık sistemindeki dönüşümlerden etkilenmiş ve toplum sağlı̆̆ hemşireliğine dönüşmüştür. Yeni durumda giderek karmaşık hale gelen sağlık sorunlarının çözümünde sağlık kurumlarına başvuran hastalar ile ilgilenmesi gerekmiştir. Dolayısıyla zamanla hastane içerisindeki artan sorumluluğu, işteki stresinin artmasına ve buna bağlı olarak iş tatmininin azalmasına neden olmuştur (Boswell, 1984, s.221).

Hemşirelerin stres kaynaklarına bakıldığında hasta bakımı, çalışma koşulları, hasta yakınlarının özel ilgi talepleri, çalışma arkadaşlarıyla yaşadıkları çatışma sonrası gerginlik, bakılacak hasta sayısının çokluğu, sosyal desteğin azlığ ş̧eklinde sıralanabilmektedir. Bu ve bunlar gibi diğer stres faktörleri iş stresini arttırmaktadır. Dolayısıyla literatürde belirtildiği gibi iş stresi çalışanlardaki iş doyumunu azaltmakta, duyarsızlaşmayı artırmakta ve devamsızlıkla başlayan işten ayrılmalara yol açmaktadır (Özaltın ve Nehir, 2007, s.61).

Hemşirelik mesleği, hastaların sağlık durumlarının yakından takip edilmesini ve anında müdahale edilmesini gerektirmektedir. Bu sebeple, hemşirelerin hastada meydana gelen değişimleri takip etmesi gerekmektedir. Dolayısıyla riskli bir iş yapmaları ve zamana karşı yarışmaları nedeniyle çalışma ortamındaki stres seviyeleri oldukça yüksektir (Öndaş Aybar ve Parlar Kılıç, 2020, s.30). Yapılan çalışmalar hemşirelerin işteki stres düzeyleri arttıkça performanslarının düştüğü, iş tatminlerinin azaldığı sonucuna ulaşılmıştır. Buna bağlı olarak hemşirelerin devamsızlığ ve işten ayrılma davranışları artan bir eğilim göstermektedir (Önder ve diğerleri, 2014, s.22).

Daha iyi bir yaşam düşüncesinin temelinde öncelikli olarak özel hayat yer alıyor gibi görünse de insanların zamanının büyük çoğunluğunu iş hayatında geçirdiği kaçınılmaz bir gerçektir. Bu gerekçeden hareketle çalışmada öncelikle stres ve işten ayrılma kavramları üzerinde durulmuştur. Kavramlara ilişkin literatüre yer verildikten sonra bir ilimizde bulunan devlet hastanesinde görev yapan hemşirelerin iş stresine bağl1 olarak algıladıkları stres semptomlarının işten ayrılma eğilimleri üzerine etkisini tespit etmeye yönelik yapılan anket çalışmasının yöntem, bulgu ve sonuçlarına yer verilmiştir.

\section{STRES VE ISSTEN AYRILMA NIYYETI KAVRAMLARI}

Çalışmada sağlık sektörü çalışanlarından hemşirelerin algıladıkları stres ve stres semptomlarının işten ayrılma eğilimleri ortaya konmaya çalışılmıştır. Bu sebeple çalışmada stres ve işten ayrılma kavramlarının literatürdeki karşılığına yer verilecektir.

\subsection{STRES}

Stres, olağandışı kısıtlama, istek, firsat ve görev ile karşılaşma durumunun bireyde yarattığı gerilim ve kaygı hissidir. Stres kavramı, mevcut ya da algılanan tehlike karşısında insan vücudundaki dengenin bozulması anlamına gelmektedir. Denge, bireyin karşılaştığı fiziksel ve duygusal tehditler nedeniyle bozulmaktadır. $\mathrm{Bu}$ sebeple, farklı kaynakların yol açtığı stres bireyler üzerinde önemli etkiler yaratmaktadır (Çankaya, 2020, s. 123; Taş ve Özkara, 2020, s. 479). Bu etkiler fizyolojik, psikolojik ve 
davranışsal boyutta gerçekleşmektedir. Bu üç boyuttaki ortak nokta ise; uyumsuz bir durumun varlığıdır. Stres çalışmayı zorlaştırabilir, fiziksel ve psikolojik semptomlara sahip olabilir. Bu semptomlar arasında en yaygın olanı, aşırı sinirlilik, yorgunluk, konsantre olma zorluğu, çaresizlik hissi, kendine güvensizlik, hızlı, dağınık düşünceler, algı kontrolü kaybı, uyku güçlüğü, iştahta değişiklikler, sindirim problemleri, baş ağrıları, isteksizlik, sık enfeksiyonlar veya hastalıklardır. Stres, çalışma yaşamında örgüt iklimini ve örgüt aidiyetini belirgin bir şekilde etkilemekte ve uyumunu bozmaktadır. Çalışanın stres ile karşılaşması halinde anksiyete ve gerginlik hissiyatının arttığı söylenebilmektedir (Erdilek Karabay, 2015, s. 118; Taş ve Özkara, 2020, s. 480).

İş stresi ise, çalışan bireyin iş yerinde sahip olduğu kapasite ve kaynaklarını aşan bir durum ile karşılaşmasıdır. İş stresi, aynı zamanda çalışan bireylerin bağlı bulundukları kurumda algıladıkları, değerlendirdikleri ve yaşadığı olumsuzluklara cevap aradığı süreci ifade etmektedir. Çalışanların işte stres yaşamaları halinde işe devam etmek istemedikleri ve devamsızlık yaptığı, işte başarı elde edemediği ve verimliliklerinin düştüğü gözlenmiştir. Bu davranışların sonucu olarak ise, depresyon, sinirlilik ve uyku problemi yaşadıkları ifade edilmektedir (Sökmen ve Şimşek, 2016, s. 610; Taş ve Özkara, 2020, s. 480).

İş stresinin yalnızca işe devamsızlığı ve işten ayrılma niyetini arttırdığını söylemek mümkün değildir. O’Neill ve Davis (2011), 164 çalışan üzerinde yaptıkları çalışmada iş stresinin daha düşük iş tatminine yol açtığ 1 ve işten ayrılma eğilimini arttırdığı sonucuna ulaşmıştır. Irawanto ve arkadaşlarının (2015) mesleki stresi belirlemek üzere Endonesya'nın en büyük ücretli otoyol işletmesinden birinde çalışan 108 kadın çalışan üzerinde yaptığı çalışmada mesleki stresin çalışanların performansını önemli ölçüde etkilediği sonucuna ulaşmıştır. Bhatti ve diğerlerinin (2016) iş stresinin bankacılık sektöründe örgütsel bağl1lık üzerindeki etkisini kontrol etmek üzere 3 farklı banka ve 30 çalışan ile yaptıkları çalışmada iş stresi ile örgütsel bağl1lık arasında negatif ve anlamlı bir ilişki olduğu sonucuna ulaşmıştır. Sonuçlar ayrıca, stresin çalışanın örgüte olan bağlılığını azaltan önemli bir faktör olduğunu ortaya koymaktadır.

\section{2. İŞTEN AYRILMA NIYETI}

İşten ayrılma niyeti, çalışan bağlı bulundukları kurumdan planlı ya da plansız olmak üzere ayrılmak istemesi halidir. Aynı zamanda bu durum, kişinin ait olduğu kurumda çalışmak istememesini ifade etmektedir. Diğer bir ifade ile işten ayrılma, çalışanın iş yapma eylemine devam etmemesi ve kurumu terk etmesi anlamına gelmektedir. İșten ayrılma, kişinin örgütten fiili olarak ayrılması olarak kabul edilirken işten ayrılma niyeti ise, kişinin davranışsal bir tutum olarak örgütten çekilme isteğini ifade etmektedir (Telli vd, 2012). İşten ayrılma niyeti, ayrılma davranışının düşünsel ve eylem boyutu arasındaki bağlantıyı kurma ve karar vermeyi ifade etmektedir. Bu niyet, ileri bir zaman aralığında kişinin örgütten ayrılması anlamına gelmektedir. Bireyi işten ayrılmaya iten faktörler arasında yaş, cinsiyet, çalışma süresi, ücret, tazminat, eğitim, alternatif iş firsatları, insan kaynakları uygulamaları, tecrübe ve örgüt kültürü gibi değişkenler yer almaktadır. İşten ayrılma davranışının psikolojik, sosyolojik ve ekonomik etkileri bulunmaktadır. Bu sebeple örgütte ciddi sorunlara yol açmaktadır (Çankaya, 2020, s. 123; Sökmen ve Şimşek, 2016, s. 611; Erdilek Karabay, 2015, s. 115; Diktaş ve Özgeldi, 2020, s. 24).

İşten ayrılma davranışı gönüllü ve gönülsüz olmak üzere iki şekilde gerçekleşmektedir. Çalışanın kendi rızası ve kişisel sebepler ile işi bırakması halinde gönüllülük durumdan bahsetmek mümkündür. Aksi halde örgüt kaynaklı sebeplerden ve bireyin örgütten beklentilerinin karşılanmaması sonucu işten ayrılması gönülsüz işten ayrılma olarak ifade edilmektedir. Bunların yanı sıra yeni bir iş imkânı elde etmesi, yüksek ücret ve daha iyi firsatlar elde edecek olması da işten ayrılma davranışının gerekçeleri arasında sayılabilmektedir (Sağır, 2020, s.96).

Kurumlar, işten ayrılma davranışı içerisinde olan çalışanları örgütte tutabilmek için bazı önlemler almak ya da mevcut çalışma koşullarında iyileştirme yapmak zorundadır. Çalışanın örgüt ile arasındaki olumsuz durum ve davranışlara sebep olan faktörlerin ortadan kaldırılması ve duygusal zekanın iyileştirilmesi halinde çalışan performansında bir artış sağlanabileceği gibi aynı zamanda işten ayrılma davranışı da engellenebilir. İşten ayrılma niyetinin erken tespit edilmesi halinde kurumlar personel kayıplarının da önüne geçebileceklerdir. Olumsuz koşulların erken teşhisi çalışanların örgütsel bağımlılık düzeyinin artmasını da sağlayacaktır (Sağır, 2020, s. 96; Diktaş ve Özgeldi, 2020, s. 24; Ciranoğlu, 2020, s. 62; Şahan, 2020, s. 125).

İşletmeler açısından bakıldığında çalışanların işyerinden ayrılması, tecrübeli ve yetenekli çalışanların 
telafisinin zor olmasının yanı sıra maliyet ve zaman kaybı olarak da değerlendirilmektedir. Çalışanın ayrılması, işletmenin rekabet imkanını yitirmesine, yeni eleman arayışına girmesine ve çalışanın işyerindeki haklarını talep etmesi halinde maliyet yüküne da yol açmaktadır. Öte yandan işyerinde meydana gelen huzursuz çalışma ortamı diğer çalışanları da olumsuz etkilemektedir (Ciranoğlu, 2020, s. $63)$.

\section{AMAÇ}

$\mathrm{Bu}$ çalı̧̧manın amacı, sağlık sektöründe yoğun iş temposuyla çalışan hemşirelerin algıladıkları stres durumları ve ortaya çıkan stres semptomlarının boyutlarını ortaya koyarak, bu semptomların işlerinden ayrılma istekleri üzerinde ne derece rol oynadığını tespit etmektir.

$\mathrm{Bu}$ amaçla bu çalışmanın temel sorunsalı;

-Hemşirelerin yaptıkları işe ilişkin stres ve işten ayrılma eğilimleri hangi düzeydedir ve aralarında anlamlı bir ilişki var mıdır?

-Hemşirelerin işe ilişkin yaşadıkları stres ve algıladıkları stres semptomlarının işten ayrılma niyeti üzerinde etkisi var mıdır? sorularına cevap aranmıştır.

\section{YÖNTEM}

$\mathrm{Bu}$ araştırma, tanımlayıcı bir çalışma olup, 2019 yılında Karaman Devlet Hastanesi’nde çalışan ve araştırmanın evrenini oluşturan 350 hemşireye Tam Sayım Yöntemi ile anket tekniği kullanılarak uygulanmıştır. Çalışmanın yapılabilmesi için Karamanoğlu Mehmetbey Üniversitesi Sağlık Bilimleri Fakültesi Girişimsel Olmayan Klinik Araştırmalar Etik Kurulu'ndan (44 sayılı ve 26.12.2012 tarihli) ve İl Sağlık Müdürlüğünden (87757741/799 sayı ve 23.02.2019 tarihli) yazılı izin alınmıştır. Ayrıca veri toplama aracı olan anketi dolduran hemşirelerden yazılı ve sözel bilgilendirilmiş onamları da alınmıştır.

Toplamda 68 sorudan oluşan anket formları, Başhekimlik aracılığı ile kapalı zarflarda hastanede çalışan tüm hemşirelere dağıtılmış ve bir hafta sonra geri toplanmıştır. Araştırmada örneklem seçimine gidilmeden evrenin tümüne ulaşmak hedeflenmiş ancak, araştırmaya katılmayı kabul eden 291 hemşire araştırmanın örneklemini oluşturmuştur. Geri dönüş yapan 291 kişiden, eksik ve hatalı doldurulan toplam 28 anket formu değerlendirilmeye alınmamıştır. Örneklemin \% 74,5'ine ulaşılmıştır.

Verilerin toplanmasında, ankette katılımcıların Demografik Özelliklerine Yönelik Bilgi Formu yer almış, ayrıca streslerini ölçmek için İşe Bağlı Stres Ölçeği, stres semptomlarını tespit etmek için Kısa Semptom Envanteri ve işten ayrılma eğilimlerini tespit etmek üzere İşten Ayrılma Niyeti Ölçeği kullanılmıştır.

a-Demografik bilgi formu; Literatür desteği ile hazırlanan (Aytaç, 2017; Sökmen ve Şimşek, 2016; O’Neill ve Davis, 2011; Özaltın ve Nehir, 2007).) hemşirelerin cinsiyeti, yaşı, medeni durumu, çalıştığı birim, çalışma yılı gibi demografik özelliklerine ilişkin sorulardan oluşmaktadır.

b-İş Stresi Ölçeği; House ve arkadaşları (1972) tarafından geliştirilen İşe Bağlı Stres Ölçeği, çalışanın iş yerinde yaşadığı stresi ölçmektedir. Ölçeğin Türkçe’ye uyarlaması Efeoğlu (2006) tarafından yapılmıştır. Ölçek maddelerinin Cronbach alfa güvenilirlik katsayıları 0.71 ile 0.89 arasında değiştiği ve Cronbach alfa güvenirlilik katsayısının 0.84 olarak tespit edildiği belirtilmektedir. Yedi sorudan oluşan 5'li likert tipi olan ölçek tek bir faktörden oluşmaktadır. Ölçekte cevaplar, 1=Kesinlikle katılmıyorum, 5=Kesinlikle katılıyorum şeklinde cevaplandırılmaktadır. Ölçek maddelerinin puan ortalamaları alınarak toplam puan hesaplanmaktadır.

c-Kısa Semptom Envanteri: Katılımcıların deneyimledikleri stres semptomlarına yönelik veriler, Derogatis (1992) tarafından geliştirilen ve Şahin \& Durak (1994) tarafından Türkçeye uyarlanarak geçerlik ve güvenilirlik çalışması yapılan Kısa Semptom Envanteri (KSE-Brief Symptom Inventory) kullanılarak toplanmıştır. Kısa Semptom Envanteri (SCL-90-R) genel bir psikopatoloji değerlendirmesi yapan beşli Likert tipi $(0=$ hiç- $4=$ çok fazla) kendini değerlendirme türü bir envanter olup, Türkçe uyarlanmasında elde edilen "Anksiyete", "Depresyon", "Olumsuz Benlik", "Somatizasyon" ve "Hostilite" olmak üzere beş faktör ve 53 maddeden oluşmaktadır (Şahin ve Durak 1994). Alt boyutlar içerik olarak incelendiğinde (Aytaç, 2017); 
Anksiyete: 13 maddelik bu alt faktör, bireyin belirli bir nesneye, duruma karşı 1srarlı korku tepkisini yansitır.

Depresyon: Genel karamsarlık, ümitsizlik, güdülenme eksikliği, intihar düşünceleri, bilişsel ve somatik belirtileri içeren yaşantı duyumsamalarını yansıtan 12 maddeden oluşur.

Olumsuz Benlik Algısı: Bireyin kendini başkalarıyla karşılaştırdığında, kişisel yetersizlik ve küçüklük duygularına kapılarak, kişiler arası ilişkilerinde kendisini küçük görmesi, bu ilişkilerde zorluk çekmesi, rahatsızlık hissetmesi gibi olumsuz düşünce ve duyguları yansıtır. 12 maddeden oluşmaktadır.

Somatizasyon: 9 maddeden oluşmakta olup, vücudun kalp, damar, mide, bağırsak, solunum ve diğer sistemlerdeki fonksiyon bozukluklarıyla ilgili sıkıntıları yansıtmaktadır. Ayrıca çözümlenemeyen engelleme veya çatışma sonucu ortaya çıan işlevsel ve fiziksel bozuklukları da tespit eder.

Hostilite, (Öfke-Düşmanlık): Kızma, huzursuz olma, karşı koyma, düşmanlık, saldırganlık, sinirlilik, öfke hali, küskünlük gibi özellikleri vurgular. 7 maddeden oluşmaktadır.

Kısa Semptom Envanteri, normal örneklemlerde olduğu gibi, çeşitli psikiyatrik ve medikal hastalarda da ortaya çıkabilecek bazı psikolojik semptomları yakalamak amacıyla geliştirilmiş çok boyutlu bir semptom tarama ölçeğidir. Ölçekten alınabilecek puan 0 ile 212 arasında değişmektedir. Ölçekten alınan puanların yüksekliği psikolojik belirtilerinin yoğunluğunu ve sıklığını göstermektedir. Ölçeğin değerlendirilmesinde her alt ölçek için belirlenen toplam, o alt ölçek için belirtilen madde sayısına bölündüğünde o boyut için puan elde edilmektedir. Ölçeğin orijinalinde Cronbach Alfa güvenirlik katsayısı 0.96' bulunmuştur (Şahin ve Durak, 1994).

d-İșten Ayrılma Niyeti Ölçeği (Predict Turnover Scale), Blau ve Boal (1989) tarafindan geliştirilen, Türkçe uyarlaması Deliorman ve arkadaşları (2009) tarafından yapılan ve geçerlilik ve güvenilirliği Türkçe çeşitli araştırmalarda test edilen işten ayrılma niyeti (İAN)ölçeği kullanılmıştır. Ölçek, kişilerin işten ayrılma eğilimlerini ölçmektedir. Toplam 4 ifadeden oluşmakta olup, 1- Hiçbir zaman, 5- her zaman seçeneklerinden ibaret 5 li Likert tipi bir ölçektir. Tek boyuttan oluşmaktadır. Ölçek maddelerinin puan ortalamaları alınarak toplam puan hesaplanmaktadır. Ölçeğin Cronbach Alfa güvenirlik katsayısı 0.86' bulunmuştur (Deliorman, Taştan Boz, Yiğit ve Yıldız, 2009).

Verilerin değerlendirilmesinde Statistical Package for the Social Sciences (SPSS) 23.0 paket program1 kullanılmıştır. Verilerin normal dağılıma uygunluğunu test etmek için veri setinin 50'den büyük olması nedeniyle Kolmogorov Smirnov testi kullanılmıştır (Altunışık vd., 2017). Yapılan normallik testinde verilerin normal dağılım göstermesi nedeniyle $(\mathrm{z}=0,71, \mathrm{p}>0,05)$ bu çalışmada parametrik analizler kullanılarak bulgulara ulaşılmıştır. Bu doğrultuda, tanımlayıcı istatistiklerin yanı sıra, çalışanlardaki "iş stresi", "stres semptomları" ve "işten ayrılma niyetleri" arasındaki ilişkilerin incelenmesinde Pearson Korelasyon Analizi, iki bağımsız grubun karşılaştırılmasında bağımsız örneklemler için t-testi ve regresyon analizi kullanılmıştır. Korelasyonel analizler iki grup değişken arasındaki bağlantılara ilişkin önemli bilgi sağlamakla birlikte, hangi semptom grup ya da gruplarının katılımcıların işten ayrılma niyetlerini yordamada daha etkili olduğu sorusunun yanıtlanmasında fayda vardır. Yaş ve çalışma süresi değişkenlerinin de kullanıldığı çoklu regresyon analizleriyle bu sorunun yanıtı aranmıştır. Analizler sonucunda elde edilen bulgular $\% 95$ güven aralığında ve $\% 5$ anlamlılık düzeyinde değerlendirilmiştir.

Araştırmada kullanılan ölçeklerin Türkçe versiyonlarının daha önce birç̧ok sayıda farklı çalışmalarda kullanıldığı ve Türkçe geçerlik ve güvenirliği genel kabul gördüğü için yap1 geçerliliğinin kontrol edilmesine gerek görülmemiş̧ir (Karakoç ve Dönmez, 2014).

\section{BULGULAR}

Araştırmaya katılan hemşirelerin yaş aralığı 20 ve 55 yaş arasında değişmekte olup, yaş ortalaması

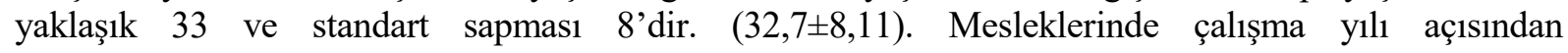
değerlendirildiğinde de 1 ile 33 yıl arasında değişen, ortalama 7 yıllık bir çalışma yıllarına sahip oldukları anlaşılmıştır $(6,8 \pm 6,92)$. Katılımcıların \% 80'i kadın, \% 20'si erkektir. Medeni durumlarına bakıldığında \% 59'unun evli, \% 36 sinın bekar olduğu görülmektedir.

Araştırmada kullanılan ölçeklerin Cronbach Alpha katsayısı ile hesaplanan iç tutarlılıkları, ölçeklere ait madde sayısı ve ortalamaları ile standart sapmaları Tablo 1'de sunulmaktadır. 
Tablo 1. Değişsenlere Illişkin Tanımlayıcı İstatistikler (Cronbach Alpha güvenirlik katsayıları, Ortalama ve Standart Sapmaları)

\begin{tabular}{|c|c|c|c|c|c|}
\hline \multicolumn{2}{|c|}{ ÖLÇEKLER } & $\begin{array}{l}\text { Madde } \\
\text { Sayısı }\end{array}$ & Ortalama & $\begin{array}{l}\text { Standart } \\
\text { Sapma }\end{array}$ & C.Alpha \\
\hline \multicolumn{2}{|c|}{ İşten Ayrılma Niyeti } & 4 & 2,79 & $\mathbf{0 , 7 3}$ & 0,79 \\
\hline \multicolumn{2}{|l|}{ İş Stresi } & 7 & 3,06 & 0,94 & $\mathbf{0 , 8 8}$ \\
\hline \multicolumn{2}{|c|}{$\begin{array}{l}\text { Kisa Semptom Envanteri } \\
\text { (KSE) }\end{array}$} & 53 & 1,03 & 0,82 & 0,98 \\
\hline \multirow{5}{*}{ Alt Boyut } & Anksiyete & 13 & 0,97 & $\mathbf{0 , 8 7}$ & $\mathbf{0 , 9 3}$ \\
\hline & Depresyon & 12 & 1,16 & 0,97 & 0,94 \\
\hline & Olumsuz Benlik & 12 & 0,99 & 0,89 & 0,93 \\
\hline & Somatizasyon & 9 & 0,91 & 0,79 & $\mathbf{0 , 8 8}$ \\
\hline & Hostilite & 7 & 1,14 & 0,82 & $\mathbf{0 , 8 3}$ \\
\hline
\end{tabular}

Çalışmada kullanılan ölçeklere ilişkin tanımlayıcı bilgiler tablo 1 de görülmektedir. İșten Ayrılma Niyeti Ölçeği 4 maddeden oluşmakta olup Cronbach Alpha iç tutarlılık katsayısı 0,79 dur, 7 maddeden oluşan İş stresi ölçeğinin Cronbach Alpha iç tutarlılık katsayısı 0,88' dir. Toplam 53 maddeden oluşan Kısa semptom envanterinin Cronbach Alpha iç tutarlılık katsayısı 0,98; olup, anksiyete alt boyutu 0,93; depresyon alt boyutu 0,94 ; olumsuz benlik alt boyutu 0,93 ; somatizasyon alt boyutu 0,88 ve hostilite alt boyutu 0,83 güvenirlik katsayılarına sahiptir.

Cronbach Alpha katsayısının 0.60 ile 0.80 arasında olması ölçeğin orta güvenilir, 0.80 ile 1.00 arasında olması ise ölçeğin yüksek güvenilir olduğunu göstermektedir (Kayış, 2009 ve Kılıç, 2016). Güvenilirlik katsayısı 0,70 'den büyük olan ölçeklerin, yeterli güvenilirliğe sahip olduğu kabul edilmektedir. Bu doğrultuda çalışmada kullanılan ölçekler yeterli güvenilirlik düzeyine sahiptir.

Kullanılan ölçeklerin toplam korelasyonları Pearson Korelasyon Analizi ile hesaplanmış ve Tablo-2'de sunulmuştur. Görülebileceği gibi, tüm korelasyon katsayıları beklenen doğrultularda gerçekleşmiştir.

Tablo 2. Değişkenler arasındaki Korelasyon Analizi

\begin{tabular}{|c|c|c|c|c|c|c|c|}
\hline & İş Stresi & $\begin{array}{l}\text { İsten } \\
\text { Ayrilma } \\
\text { Niyeti }\end{array}$ & KSE & Anksiyete & Depresyon & $\begin{array}{l}\text { Olumsuz } \\
\text { Benlik }\end{array}$ & Somatizasyon \\
\hline İşten Ayrılma Niyeti &, ,338 $^{\text {** }}$ & 1 & & & & & \\
\hline KSE &, $289^{* * *}$ &, $164^{* *}$ & 1 & & & & \\
\hline Anksiyete &, $247^{* *}$ & ,149* & ,964** & 1 & & & \\
\hline Depresyon &, $282^{* *}$ & ,191*** &, $953^{* *}$ &, $\mathbf{8 8 9}^{* * *}$ & 1 & & \\
\hline Olumsuz Benlik &, $252^{* *}$ &, 110 &, $957^{* *}$ & ,922** &, $\mathbf{8 8 5} 5^{* *}$ & 1 & \\
\hline Somatizasyon &, $255^{* *}$ &, $121^{*}$ &, $906^{* *}$ &, $844^{* *}$ &, $831^{* *}$ &, $819^{* * *}$ & 1 \\
\hline Hostilite &, $\mathbf{3 5 3}^{* * *}$ &, $210^{* *}$ &, $861^{* *}$ &, $\mathbf{7 8 5}^{* *}$ & ,782** & $\mathbf{7 8 3}^{* * *}$ &, $768^{* *}$ \\
\hline
\end{tabular}

**. Correlation is significant at the 0.01 level (2-tailed). *Correlation is significant at the 0.05 level (2tailed).

Ölçekler arasındaki korelasyonlar incelendiğinde işten ayrılma niyeti, iş stresi ve stres semptomları arasında pozitif yönde anlamlı ilişki olduğu görülmektedir. Ancak, işten ayrılma niyeti toplam puanı ile Kısa Semptom Envanteri'nin alt boyutları arasındaki korelasyonlar olumsuz benlik alt semptomu hariç diğerleriyle pozitif yönde ve istatistiksel açıdan anlamlı olmakla birlikte, en yüksek korelasyon "hostilite" semptom grubuyla elde edilmiştir $(\mathrm{r}=0.21, \mathrm{p}>0.001)$. Bireylerin hostilite yani öfke, düşmanlık, kızgınlık, 
düzeyleri arttıkça, işten ayrılma niyetleri de artmaktadır. Diğer taraftan iş stresindeki artışın da işten ayrılma niyetini arttırdığı görülmektedir $(r=0,34, \mathrm{p}>0.001)$.

Alt boyutlar incelendiğinde, stres değişkeninin tüm semptom gruplarıyla \%1 anlam düzeyinde pozitif ve anlamlı ilişkiler sergilediği görülmektedir. Yine hostilite semptom grubu işe ilişkin stresle en yüksek pozitif korelasyonu $(0.35 ; \mathrm{p}>0.001)$ sergilemektedir. Diğer taraftan Depresyon semptom grubuna ait korelasyon incelendiğinde $(0,28 ; \mathrm{p}>0.001)$ stresle pozitif yönde yüksek korelasyon sergilediği anlaşılmaktadır. İşten ayrılma niyeti ile semptom grupları arasındaki ilişkide anlamlılık düzeyine ulaşmayan katsayı olumsuz benlik semptom grubuna aittir $(0.11 ; \mathrm{p}<0.01)$. Anksiyete ve Somatizasyon semptomları ise işten ayrılma niyeti ile $\% 5$ anlamlılık düzeyinde bir ilişkiye sahiptir. Hostilite semptom grubu değişkeninin iş stresi ve işten ayrılma niyeti ile en yüksek pozitif ilişkiye sahip olduğu anlaşılmaktadır (stres için 0.35 ; işten ayrılma niyeti için 0.21 ; p'ler $>0.001$ ); bireyin iş stresinin varlığ 1 , hostilite semptomlarındaki artışa neden olmakta ve beraberinde genel memnuniyetsizliği belirten işten ayrılma olasılı̆̆ı da artmaktadır.

Hangi stres semptom gruplarının katılımcıların ișten ayrılma niyetlerini yordamada daha etkili olduğu sorusuna cevap aramak için çoklu regresyon analizi uygulanmıştır. Regresyon analizinde iki ayrı değişken grubuna (stres ve semptom gruplarına) yaş ve çalışma süresi değişkenleri de sırayla regresyon denklemine eklenmesi yoluyla gerçekleştirilmiştir; böylece, özellikle semptom gruplarının açıklanan varyansa katkı miktarlarının da saptanması hedeflenmiştir.

Tablo 3. Işsten Ayrılma Niyeti Üzerinde Etkide Bulunan Değişkenlerin Çoklu Regresyon Analizi

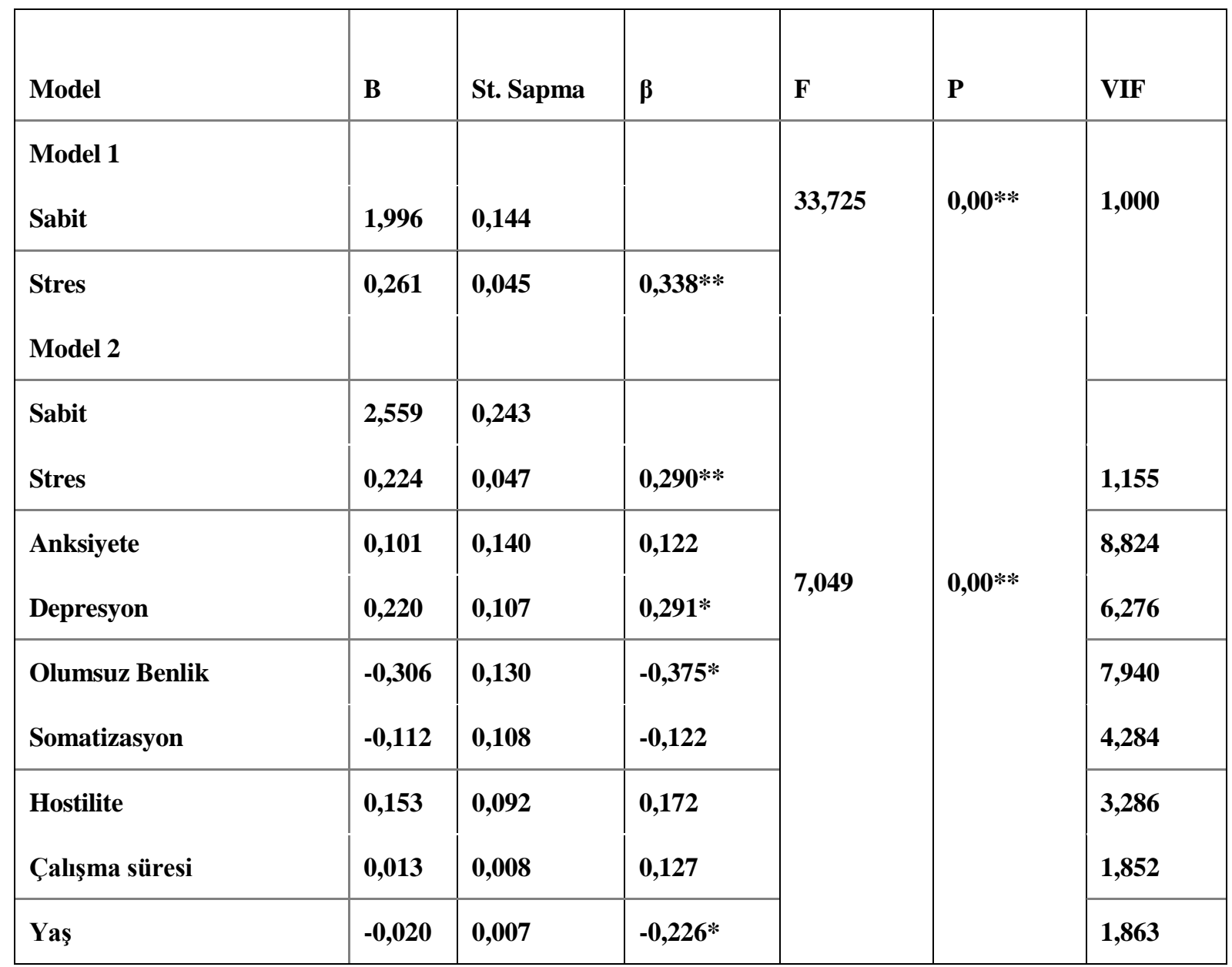

Not: Model 1 için R2 = 0,12 (p <0,001); Model 2 için R2=0,19 $(\mathrm{p}<0,001) * *, p<0,05^{*}$

Durbin Watson $=1,904$

Model 1, işten ayrılma niyetini stres değişkeni tek başına varyansın \%12 sini açılkarken, Model 2 de stres, yaş, çalışma süresi ve stres semptomlarının tümü modele eklendiğinde varyansın \%19 unu açıklamaktadır. 
Kurulan bu çoklu regresyon modeli istatistiksel olarak anlamlıdır. Model 2 de stres, Depresyon, Olumsuz benlik ve Yaş değişkenlerinin istatistiksel açıdan anlamlı bir ilişki içinde olduğu, özellikle Olumsuz benlik ve yaş değişkenlerinin negatif etkisi olduğu anlaşılmaktadır. Diğer bir ifade ile işten ayrılma niyeti üzerinde stres değişkeninin önemli bir etkisi olduğu, diğer taraftan stres semptomlarından depresyon ve olumsuz benlik değişkenleri ile birlikte yaş değişkeninin de yordayıcı etkisi olduğu anlaşılmaktadır.

Kurulan regresyon modelinin Durbin-Watson katsayısı 1,904 olması ve varyans şişkinlik değerlerinin (VIF) 10'dan düşük değerler alması, bağımsız değişkenler arasında çoklu bağlantının ve otokorelasyonun olmadığını göstermiştir.

Ayrıca, çalışmada stres, stres semptomları ve alt boyutları ile işten ayrılma eğiliminin cinsiyete göre farklılığını test etmek amacıyla $t$ testi yapılmış, ancak ölçekler ve stres semptomlarına ilişkin alt boyutlarla cinsiyet arasında ilişki bulunamamıştır ( $\mathrm{p}>0.05)$. Diğer bir ifade ile bu çalışmada iş stresi, stres semptomları ve işten ayrılma eğilimlerinin cinsiyete göre farklılık göstermediği tespit edilmiştir.

Elde edilen bulgulara göre, hemşirelerin iş stresi ile işten ayrılma niyetleri arasında aynı yönde anlamlı bir ilişki olduğu, ayrıca hemşirelerin iş stresi ve algıladıkları stres semptomlarının işten ayrılma niyeti üzerinde etkisi olduğu anlaşılmıştır. Elde edilen bulguların, araştırmanın temel sorularına yanıt verdiği görülmektedir.

\section{GENEL DEĞERLENDIRME VE SONUÇ}

Yoğun ve yorucu çalışma saatlerinin yanında aşırı iş yükü altında bulunan hemşirelik mesleği, işten ayrılma davranışının en yoğun görüldüğü mesleklerden biridir. Bu araştırma, önemli bir meslek grubu olan sağlık çalışanlarından hemşirelerin iş stresleri ve stres semptomlarının işten ayrılma eğilimleri ile olan ilişsilerini incelemek amacını taşımaktadır. İşten ayrılma eğiliminin stres semptomlarıyla tutarlı korelasyonlar sergileyeceği beklentisi, araştırmanın temel hedefini oluşturmuştur. Bu doğrultuda yapılan çalışmanın diğer uygulamalar doğrultusunda karşılaştırmalı bir çalışma olması açısından ilgili yazına teorik ve uygulama bağlamında katkısı olacağı düşünülmektedir.

Hemşirelerin iş stresleri, stres semptomları ve işten ayrılma eğilimleri 263 kişilik bir hemşire örnekleminden elde edilmiştir. Anksiyete, depresyon, olumsuz benlik, somatizasyon ve hostilite adını taşıyan beş ana semptom grubuna ilişkin verilerin işten ayrılma eğilimiyle olan bağlantıları korelasyon ve regresyon teknikleriyle incelenerek söz konusu bulgulara ulaşılmıştır. Elde edilen sonuçlar alan yazındaki sonuçlarla uygunluk göstermektedir.

Aytaç (2011), bir üniversite hastanesinde görev yapan 178 yardımcı sağlık personeli üzerinde yaptığı çalışmada, sağlık çalışanlarının işe ilişkin duygularının stres tepkileri üzerindeki etkisini İşe İlişskin Duygusal İyilik Hali Ölçeği ve Kısa Semptom Envanteri ile araştırmış, elde ettiği bulgulara göre sağlık çalışanlarının işlerine ilişkin iyilik hallerindeki olumsuz duygu durumlarının tüm stres semptom gruplarıyla pozitif yönde anlamlı ilişkiler sergilediği, olumlu duygu durumlarının ise, somatizasyon grubu hariç, diğer tüm stres semptom gruplarıla negatif ilişki içinde olduğu sonucunu elde etmiştir. Aytaç'ın (2011) elde ettiği bulgular bu çalışmanın sonuçları ile örtüşmektedir.

Rickard ve arkadaşlarının (2012), 484 hemşire üzerinde yaptığı çalışmada, hemşirelerin mesleki streslerinin ve işten ayrılma oranlarının azaltılmasına yönelik örgütsel müdahalenin etkisini değerlendirmiştir. Hemşirelerin stres halinde işteki verimliliklerinin azaldığ 1 , performanslarının düştüğü, devamsızlık yaptığı ve en önemlisi işten ayrılma niyetleri olduğu sonucu elde edilmiştir. Benzer bir ifadeyi bu çalışma için de söylemek mümkündür. Hemşirelerdeki iş stresinin varlığı, hostilite semptomlarındaki artışa neden olmakta ve beraberinde genel memnuniyetsizliği belirten işten ayrılma niyeti de artış göstermektedir.

Yüksel (2015) tarafından hemşirelik öğrencilerinin ruhsal belirti durumlarını ve etkilediği düşünülen faktörlerin belirlenmesi amacıyla yapılan araştırmada, öğrencilerin somatizasyon puan ortalamalarının sınıf değişkeni farkı istatistiksel açıdan anlamlı bulunmuştur. İkinci sınıf öğrencilerinin somatizasyon puanı 3 ve 4. Sınıf öğrencilerinin puanından daha yüksek olduğu anlaşılmıştır. Öğrencilerin cinsiyetlerine, üniversite yaşamlarında kaldıkları yere, ailesiyle yaşadığı yer, aile ve kendi ekonomik durumunu değerlendirmelerine göre yapılan gruplamalarda ise Kısa Semptom Envanteri toplam ve alt ölçek puan ortalamaları istatistiksel açıdan anlamlı düzeyde farklılık göstermemiştir. 
Erdilek Karabay'ın (2015) İstanbul'da faaliyet gösteren özel hastanede çalışan 206 sağllk personeli ile yaptığı çalışmada iş stresinin işten ayrılma niyetini ortaya çıkarmayı amaçlamıştır. Çalışanların maruz kaldığı iş stresinin işten ayrılma niyetini arttırdığını ve iş-özel yaşam üzerinde çatışma etkisi yarattığı sonucuna ulaşmıştır. Karabay'ın çalışmasında elde ettiği bulgular bu çalışmayı destekler niteliktedir.

Aytaç (2017), Stres Kaynakları ve Stres Semptomlarının Öfke Kontrolü ile İlişkisini ölçmek üzere 5725 Polis memuru üzerinde yaptı̆̆ bir çalışmada, stres kaynakları, stres semptomları ve öfke tarzları arasında anlamlı bir ilişki bulunmuştur. Aytaç'ın (2017) araştırma sonuçlarına benzer sonuçları bu çalışmada da görmek mümkündür. Ölçekler arasındaki korelasyonlar incelendiğinde işten ayrılma niyeti, iş stresi ve stres semptomları arasında pozitif yönde anlamlı ilişki olduğu görülmektedir. Ancak, işten ayrılma niyeti toplam puanı ile KSE'nin alt boyutları arasındaki korelasyonlar olumsuz benlik alt semptomu hariç diğerleriyle pozitif yönde ve istatistiksel açıdan anlamlı olmakla birlikte, en yüksek korelasyon "hostilite" semptom grubuyla elde edilmiştir $(\mathrm{r}=0.21, \mathrm{p}>0.001)$. Bireylerin hostilite yani öfke, düşmanlık, kızgınlık, düzeyleri arttıkça, işten ayrılma niyetleri de artmaktadır. Diğer taraftan iş stresindeki artışın da işten ayrılma niyetini arttırdığı görülmektedir $(\mathrm{r}=0,34, \mathrm{p}>0.001)$.

Çelik ve Yıldız (2018) hemşirelerde mesleki bağlılığın örgütsel özdeşleşme ve işten ayrılma niyeti üzerindeki etkisi ölçmeyi amaçlamıştır. Gaziantep ilinde bulunan hastanelere çalışan 428 kamu ve 239 özel sektör çalışanı ile yaptıkları çalışmada mesleki bağlılığın ve özdeşleşmenin işten ayrılma niyetini negatif düzeyde anlamlı etkilediği anlaşılmıştır.

Öndaş Aybar ve Parlar Kılıç (2020) bir ilimizde bulunan üniversite hastanesi yoğun bakım ünitelerinde çalışan 165 hemşire üzerinde yaptığ 1 çalışmada hemşirelerin etik sorunlar karşısında maruz kaldıkları stres düzeylerini belirlemeyi amaçlamıştır. Bu doğrultuda hemşirelerin algıladıkları stres düzeylerinin yüksek olduğu sonucuna ulaşılmıştır. Bu sonuç, bizim çalışmamızla da benzerlik göstermekte olup hemşirelerin iş stresinin yüksek olduğu anlaşılmaktadır.

Çankaya (2020) bir hastanede 256 sağlık çalışanı üzerinde yaptığ çalışmada iş stresinin işten ayrılma eğilimine etkisini ölçmüştür. Çalışmanın sonunda stresin işten ayrılma niyeti üzerinde anlamlı bir etkisinin olduğu ve çalışanların işten ayrılma davranışlarının \%24,5 oranında stres kaynaklı olduğu sonucuna ulaşmıştır. Benzer sonuçlara bu çalışmada da ulaşılmıştır. Hostilite semptom grubu değişkeninin iş stresi ve işten ayrılma niyeti ile en yüksek pozitif ilişkiye sahip olduğu anlaşılmaktadır (stres için 0.35 ; işten ayrılma niyeti için 0.21 ; p'ler $>0.001$ ); bireyin iş stresinin varlığı, hostilite semptomlarındaki artışa neden olmakta ve beraberinde genel memnuniyetsizliği belirten işten ayrılma olasılı̆̆ da artmaktadır.

Özçelik Kaynak ve Öztuna (2020), sözleşmeli olarak göreve yeni başlayan 119 hemşire ile yaptıkları çalışmada hemşirelerin işten ayrılma eğilimlerini ölçmeyi amaçlamışlardır. Bir yıl içerisinde 119 hemşireden 42'sinin işten ayrıldığı sonucuna ulaşmışlardır. Yapılan çalışmada her üç hemşireden birinin yıl sonunda kurumdan ayrıldığı tespit edilmiştir. Çalışmada, hemşirelerin örgütsel bağl1lık düzeyinin düşük ve işten ayrılma eğiliminin yüksek olduğu anlaşılmıştır.

Literatürde çalışma konusu ile benzerlik kurulan araştırmalardan elde edilen sonuçlara göre; hemşirelerin maruz kaldıkları iş stres düzeylerinin işten ayrılma eğilimleri üzerinde etkisi olduğu bilgisine ulaşılmıştır. $\mathrm{Bu}$ çalışmada da stresin çalı̧̧anların işten ayrılma niyetini etkilediği ve çalı̧̧anların işten ayrılma nedenlerinin genellikle stres kaynaklı olduğu konusunda alan yazınındaki benzer çalışmalarla örtüşen sonuçlar elde edildiğini söylemek mümkündür.

$\mathrm{Bu}$ çalışmada, araştırmanın temel sorunsalı olarak belirtilen, "hemşirelerin iş stresi ve işten ayrılma niyeti arasında anlamlı bir ilişki olduğu ve stres semptomlarının da işten ayrılma niyetini etkilediği" sonucuna ulaşılmıştır.

Çalışmanın sadece bir ilimizdeki devlet hastanesinde uygulanmış olması ve verilerin sadece anket yöntemiyle elde edilmiş olması çalışmanın kısıtlarını oluşturmaktadır. Başka çalışmalarda farklı özel ve devlet hastanelerinde farklı örneklem grupları üzerinde ve hatta değişik sektörlerde benzer çalışmaların uygulanması durumunda daha farklı sonuçlara ulaşılabilecektir. Çalışma, sağlık sektöründe faaliyet gösteren bir hastanede çalışan hemşirelerin stres, stres semptom göstergeleri ve işten ayrılma eğilimlerinin ele alması bakımından önem taşımaktadır. 


\section{Bilgilendirme / Acknowledgement:}

\section{Yazarlar așağıdaki billgilendirmeleri yapmaktadırlar:}

1- Araştırmacıların katkı oranı şu şekildedir: 1. Yazar: \%35 2. Yazar: \% 35. Yazar: \%30

2- Bu çalışmanın özeti, 01-02.09.2020 tarihleri arasında düzenlenen 5th International Scientific Research E-Congress (IBAD-

2020) etkinliğinde sunulmuştur. Ayrıca çalışmanın özet metni kongre özet kitapçığında yayınlanmıştır.

3- Makalenin yazarları arasında çıkar çatışması bulunmamaktadır.

4- Karamanoğlu Mehmetbey Üniversitesi Sağlık Bilimleri Fakültesi Girişimsel Olmayan Klinik Araştırmalar Etik Kurulu'ndan (44 sayılı ve 26.12.2018 tarihli) ve İl Sağlık Müdürlüğünden (87757741/799 sayı ve 23.02.2019 tarihli) yazılı izin alınmıştır.

5- Bu makalede araştırma ve yayın etiğine uyulmuştur.

\section{KAYNAKÇA}

Altunışık R., Coşkun R., Bayraktaroğlu S., Yıldırım E. (2017). Sosyal bilimlerde araştırma yöntemleri (SPSS uygulamalı). 9. Baskı. Sakarya: Sakarya Yayıncılık.

Aytaç, S. (2017). Stres kaynakları ve stresin psikolojik semptomlarının öfke kontrolü ile ilişkisi: polis memurları üzerine bir araştırma. Sosyal Siyaset Konferansları, 69(2), 1-27

Aytaç, S. (2011). Çalışanların işlerine ilişkin duygularının stres tepkileri üzerindeki etkisi. Ístanbul Üniversitesi İktisat Fakültesi Mecmuast, 55(1), 833-851.

Bhatti, M. H., Bhatti, M. H., Akram, M. U., Hashim, M. ve Akram, Z. (2016). Relationship between job stress and organizational commitment: An empirical study of banking sector. Journal of Business Management and Economics, 7(1), 29-37.

Blau G., Boal K., (1989). Using job involvement organizational commitment interactively to predict turnover. Journal of Management, 15(1), 115-127.

Boswell C. A. (1992). Work stress and job saticfaction for the community health nurse. Journal of Community Health Nursing, 9(4), 221-227.

Cıranoğlu M. (2020). Etkileşimci Liderlik yaklaşımının hemşirelerin işten ayrılma niyetlerine etkisi ve işten ayrılma niyetinin demografik faktörlerle ilişkisi: Bursa ilinde özel hastanelerde bir alan araştırması. Eskişehir Osmangazi Üniversitesi İIBF Dergisi, 15(1), 61-80.

Çankaya M. (2020). Hastane çalışanlarındaki iş stresinin işten ayrılma niyeti üzerindeki etkisi. Business and Management Studies: An International Journal, 8(1), 121-143.

Çelik M., Yıldız B. (2018). Hemşirelerde mesleki bağl1lık, özdeşleşme ve işten ayrılma niyeti ilişkisi: kamu sektörü ve özel sektör karşılaştırması. Kastamonu Üniversitesi İ̈BF Dergisi, 20(2), 47-75.

Deliorman R. B., Taştan Boz İ., Yiğit İ., Yıldız S. (2009). Tükenmişliği ölçmede alternatif bir araç: Kopenhag tükenmişlik envanterinin Marmara üniversitesi akademik personeli üzerine uyarlanması. İ. Ü. Yönetim Dergisi, 20(63), 77-98.

Derogatis, L.R (1999). The brief symptom inventory-BSI administration, scoring and procedures manualII. USA: Clinical Pscyhometric Research Inc.

Derogatis, L.R. ve Cleary, P. A. (1977). Comfirmation of dimensiyonal structure of the SCL-90: A study in construct validation. Journal of Clinical Psychology, 33(4), 981-989.

Derogatis, L.R., Lazarus, L. (1994). SCL 90-R Brief symptom inventory and matching clinical rating scales. (Ed. Maruish M. E.). The use of psychological testing for treatment planning and outcome assessment içinde. 217-248. USA: Lawrence Erlbaum Associates. 
Diktaş G., Özgeldi M. (2020). Çalışan performansı ve işten ayrılma niyeti konularında örgütsel sinizm ve sosyal zekânın rolü. Yönetim ve Ekonomi Araştırmaları Dergisi, 18(2), 11-28.

Efeoğlu İ.E. (2006). İ̧-aile yaşam çatışmasının iş stresi, iş doyumu ve örgütsel bağlllık üzerindeki etkileri: ilaç sektöründe bir araştırma. Yayımlanmamış Doktora Tezi, Çukurova Üniversitesi Sosyal Bilimler Enstitüsü, Adana.

Erdilek Karabay M. (2015). Sağlı personelinin iş stresi, iş- aile çatışması ve iş-aile-hayat tatminlerine yönelik algılarının işten ayrılma niyeti üzerindeki etkilerinin belirlenmesi üzerine bir araştırma. Yönetim Bilimleri Dergisi, 13(26), 113-134.

House, R. J., Rizzo, J. R. (1972). Role conflict and ambiguity as critical variables in model of organizational behavior. Organizational Behavior and Human Performance, 7, 467-505.

Irawanto, D. W., Noermiyati, Primasari, D. (2015). The effect of occupational stress on work performance of female employees: Study in Indonesia. Asia-Pacific Journal of Management Research and Innovation, 11(4), 336-345.

Karakoç A., Dönmez P. (2014). Ölçek geliştirme çalışmalarında temel ilkeler. Tıp Eğitimi Dünyası, 13(40), 39-49.

Newlin B. (1984). Stress reduction for the critical care nurse: a stress education program. Occupational Health Nursing, June, 315-319.

O’Neill, J. W. ve Davis, K. (2011). Work stress and well-being in the hotel industry. International Journal of Hospitality Management, 30(2), 385-390.

Öndaş Aybar D., Parlar Kılıç S. (2020). Bir üniversite hastanesinde çalışan yoğun bakım hemşirelerinin karş1laştıkları etik sorunlarun stres düzeylerine etkisi. Düzce Üniversitesi Sağllk Bilimleri Enstitüsü Dergisi, 10(1), 29-35.

Önder G., Aybas M., Önder E. (2014). Hemşirelerin stress seviyesine etki eden faktörlerin öncelik sırasının çok kriterli karar verme tekniği ile belirlenmesi. Optimum Journal of Economics and Management Sciences, 1(1), 21-35.

Özaltın G., Nehir S. (2007). Ankara ilindeki hastanelerin yoğun bakım ünitelerinde çalışan hemşirelerin iş ortamındaki stress etkenleri ve kullandıkları başetme yöntemlerinin belirlenmesi. Atatürk Üniversitesi Hemşirelik Yüksekokulu Dergisi, 10(3), 60-68.

Özçelik Kaynak K., Öztuna B. (2020). İşe yeni başlayan hemşirelerin örgütsel bağlllıkları ile personel devir oranları: dokuz eylül üniversitesi hastanesi hemşireleri üzerine bir araştırma. Nazilli İktisadi ve İdari Bilimler Fakültesi Dergisi, 1(1), 27-38.

Rickard, G., Lenthall, S., Dollard, M., Opie, T., Knight, S., Dunn, S., Wakerman, J., Macleod, M., Seiler, J. and Brewster-Webb, D. (2012). Organisational intervention to reduce occupational stress and turnover in hospital nurses in the northern territory. Australia, Collegian, 19(4), 211-221.

Sağır M. (2020). Cam tavan sendromunun bankacılık sektöründe çalışan kadınlarda işten ayrılma niyetine etkileri. Stratejic Public Management Journal, 6(11), 91-102.

Selye H. (1976). The stress of life. (2nd ed.). New York: McGraw-Hill.

Sökmen A., Şimşek T. (2016). Örgütsel bağl1lık, örgütle özdeşleşme, stres ve işten ayrılma niyeti ilişkisi: bir kamu kurumunda araştırma. Gazi Üniversitesi IIIBF Dergisi, 18(3), 606-620.

Şahan S. (2020). Hemşirelikte örgütlenme ve örgütsel bağl1lık. Türkiye Klinikleri Tip Etiği-Hukuku-Tarihi Dergisi, 28(1), 122-127.

Şahin, N. ve Durak, A. (1994). Kısa semptom envanteri (brief symptom inventory- BSI): Türk gençleri için uyarlaması. Türk Psikoloji Dergisi, 9(31), 44- 56.

Taş A., Özkara Z. U. (2020). İş stresinin algılanan yönetici desteği ile işten ayrılma niyeti arasındaki ilişkide üstlendiği rol. Uluslararası Toplum Araştırmaları Dergisi, 15(21), 475-504. 
Telli E., Ünsar, A. S. Ve Oğuzhan, A. (2012). Liderlik davranış tarzlarının çalışanların örgütsel tükenmişlik ve işten ayrılma eğilimleri üzerine etkisi: konuyla ilgili bir uygulama. Electronic Journal of Vocational Colleges, 2, 135-150.

Yüksel A. (2015). Hemşirelik öğrencilerinin ruhsal durumları ve etkileyen faktörlerin incelenmesi. Gümüşhane Üniversitesi Sağlık Bilimleri Dergisi, 4(2), 215-226. 